\title{
Gıda örneklerinden izole edilen Enterococcus türlerinin çeşitli virülans özellikleri, biyofilm oluşumu ve antibiyotik dirençliliklerinin belirlenmesi
}

\author{
Tuğçe Gürkan ${ }^{1}$, Meryem Burcu Külahc1 ${ }^{2 *}$, Sumru Çıtak ${ }^{3}$ \\ ${ }^{1}$ Gazi Üniversitesi, Fen Fakültesi, Biyoloji Bölümü, Ankara, Türkiye, (ORCID:0000-0002-1999-3319), tugcegurkan@gazi.edu.tr \\ $2^{2 *}$ Gazi Üniversitesi, Fen Fakültesi, Biyoloji Bölümü, Ankara, Türkiye (ORCID: 0000-0002-5007-5209), meryemburcu@gazi.edu.tr \\ ${ }^{3}$ Gazi Üniversitesi, Fen Fakültesi, Biyoloji Bölümü, Ankara, Türkiye ( ORCID: 0000-0003-1925-0483), scitak@gazi.edu.tr
}

(1st International Conference on Applied Engineering and Natural Sciences ICAENS 2021, November 1-3, 2021)

(DOI: 10.31590/ejosat.1012135)

\begin{abstract}
ATIF/REFERENCE: Gürkan, T., Külahcı, M. B. \& Çıtak, S. (2021). Gıda Örneklerinden İzole Edilen Enterococcus Türlerinin Çeşitli Virülans Özellikleri, Biyofilm Oluşumu ve Antibiyotik Dirençliliklerinin Belirlenmesi. European Journal of Science and Technology (28), 924-932.

$\ddot{O} \mathbf{z}$

Çalışmamızda Eylül -Aralık 2020 tarihlerinde 20 çiğ süt, 20 peynir, 20 çiğ tavuk eti, ve 20 çiğ et olmak üzere 80 adet gıda ürününden izole edilen Enterococcus izolatlarının tanımlanması için temel biyokimyasal testler ve identifikasyon işlemi MALDI-TOF Kütle Spektrofotometresi ile yapılarak 60 izolattan 42 (\%70) Enterococcus faecalis ve 18 (\%30) Enterococcus faecium türü izole edilmiştir. E.faecalis ve E.faecium türlerinin Kirby-Bauer disk difüzyon metoduyla antibiyotik direnç profilleri, lipaz, jelatinaz, DNaz aktiviteleri, hemolitik aktivitesi, $\mathrm{S}$ tabakası varlığı ve biyofilm aktiviteleri incelenmiştir. E.faecalis türlerinin en fazla duyarlı olduğu antibiyotikler \%100 kloramfenikol, streptomisin, vankomisin ve teikoplanin, $\% 97,6$ gentamisin ve norfloksasin, $\% 95,2$ ampisilin, $\% 92,8$ siprofloksasin olarak saptanmıştır. En fazla dirençlilik gösterdiği antibiyotik \%90,4 tetrasiklindir. E.faecium türlerinin en fazla duyarlı olduğu antibiyotikler \%100 ampisilin, kloramfenikol, streptomisin, gentamisin, vankomisin ve teikoplanin, \% 77,7 siprofloksasin, \%72,2 norfloksasindir. En fazla dirençlilik gösterdiği antibiyotik \%61,1 tetrasiklindir. Lipaz ve jelatinaz aktiviteleri tümünde negatif, DNaz aktiviteleri ise tümünde pozitif sonuç vermiştir. S tabakası varlığı E.faecalis'te $\% 83,3$ ve E.faecium'da $\% 16,6$ bulunmuştur. Biyofilm aktiviteleri Kongo Red Agar'da 60 adet Enterococcus spp. türü bakterinin 2'si (\%3.3) kuvvetli, 22'si (\%36.6) orta kuvvetli, 36's1 (\%60) zayıf biyofilm pozitif üretmiştir. Mikroplak yönteminde E.faecalis'te 32'si (\%53,3) zayıf, 8'i (\%13,3) orta kuvvetli, 2'si $(\% 3,3)$ kuvvetli biyofilm üretmiş̧ir. E.faecium'da 17'si $(\% 28,3)$ zayıf, 1'i $(\% 1,6)$ orta kuvvetli biyofilm üretmiştir. Kuvvetli biyofilm üreten Enterococcus türleri saptanmamıştır.
\end{abstract}

Anahtar Kelimeler: Gıda, Enterococcus, Virülans özellikler, Virülans genler, Biyofilm oluşumu, Antibiyotik dirençliliği, Disk difüzyon.

\section{Determination of various virulence properties and biofilm formation antibiotic resistance of enterococcus species isolated from food samples}

\begin{abstract}
In our study, basic biochemical tests and identification process for the identification of Enterococcus isolates isolated from 80 food products, including 20 raw milk, 20 cheese, 20 raw chicken meat, and 20 raw meat, between September and December 2020, were performed with MALDI-TOF Mass Spectrophotometer and 42 of 60 isolates were identified. (70\%) Enterococcus faecalis and 18 (30\%) Enterococcus faecium species were isolated. Antibiotic resistance profiles, lipase, gelatinase, DNase activities, hemolytic activity, presence of S layer and biofilm activities of E.faecalis and E.faecium species were investigated by Kirby-Bauer disc diffusion method. The antibiotics to which E.faecalis species were most susceptible were found to be $100 \%$ chloramphenicol, streptomycin,
\end{abstract}

* Sorumlu Yazar: meryemburcu@gazi.edu.tr 
vancomycin and teicoplanin, 97.6\% gentamicin and norfloxacin, 95.2\% ampicillin, 92.8\% ciprofloxacin. The antibiotic with the highest resistance is $90.4 \%$ tetracycline. The antibiotics to which E.faecium species are most susceptible are $100 \%$ ampicillin, chloramphenicol, streptomycin, gentamicin, vancomycin and teicoplanin, $77.7 \%$ ciprofloxacin, $72.2 \%$ norfloxacin. The antibiotic with the highest resistance is $61.1 \%$ tetracycline. Lipase and gelatinase activities were negative in all, and DNase activities were positive in all. Presence of S layer was found $83.3 \%$ in E.faecalis and $16.6 \%$ in E.faecium. Biofilm activities of 60 Enterococcus spp. on Congo Red Agar. Of the bacteria, 2 (3.3\%) were strong, $22(36.6 \%)$ were medium strong, and $36(60 \%)$ were weak biofilm positive. In the microplate method, $32(53.3 \%)$ weak, $8(13.3 \%)$ medium-strong, $2(3.3 \%)$ strong biofilms were produced in E.faecalis. In E.faecium, $17(28.3 \%)$ produced weak biofilms and 1 (1.6\%) produced medium-strength biofilm. Strong biofilmproducing Enterococcus species were not detected.

Keywords: Food, Enterococcus species, Enterococcus, Enterococci, Virulence determinants, Virulence genes, Biofilm formation, Antibiotic resistance, Disc diffusion.

\section{Giriș}

Enterococcus'lar, insan ve hayvanlarda gastrointestinal florada bulunup ve hayvanlardan elde edilen besin ürünlerinde olduğu gibi insan ve hayvan kaynaklı kanalizasyon ve. fekal materyaller tarafından kontamine olmuş ortamlarda yaygındırlar [1], [2]. Hayvanların bağırsak florasındaki yaygınlığa göre hayvansal gıdalar başta olmak üzere pek çok gıdada bulunabilirler. $\mathrm{Bu}$ yüzden bazı çalışmalarda E.faecalis ve E.faecium'un fekal kontaminasyon göstergesi olarak değerlendirildiği görülmektedir [3]. Enterococcus 'ların gıdalarda yetersiz hijyen indikatörü olarak değil aynı zamanda gıdanın bir parçası olarak da göz önüne alınması gerekmektedir [3], [4]. Aynı zamanda Enterococcus 'lar 1 șl işlem görmüş et ürünlerinde yüksek sıcaklığa karşı dirençli olma özelliğinden dolayı pastörizasyon sonrası canlı kalırlar. Dilimleme ve paketleme gibi işlem basamaklarında çapraz kontaminasyona bağlı olarak üründe bozulma yapabilmektedirler. $\mathrm{Bu}$ bakteriler, istenmeyen özelliklerinin yanında birçok yararlı özelliklerinden dolayı gıda endüstrisinde starter, yardımcı kültür (adjunct) ve probiyotik olarak da kullanılmaktadır [3], [4], [5]. Normal floranın firsatçı patojenleri olarak tanınan Enterococcus'lar, hastane enfeksiyon etkenleri arasında ilk sıralarda yer almaktadır. Bazı suşlarının yararlı özelliklerinin yanında Enterococcus ların en yaygın hastane kaynaklı patojenlerin arasında yer aldığı, özellikle de $E$. faecium ve E. faecalis'in firsatçı patojen olduğu, bakteriyemi ve endokarditisin gibi hastalıklarla beraber üriner sistemde ve merkezi sinir sistemi gibi dokularda enfeksiyonlara neden olabildiği bildirilmektedir. Enterococcus'ların patojenite mekanizmalarında vankomisin gibi bazı antibiyotiklere direnç özelliklerinin ve sahip oldukları çeşitli virülans faktörlerinin önemli rolü olduğu belirtilmektedir [4].

Enterococcus'ların insan sağlığı açısından dikkat çekmesinin nedenlerinden biri antibiyotiklere direnç özellikleridir. Antibiyotik dirençliliği, Enterococcus'ların hastane ortamında canlılığını sürdürmesine ve dirençli suşların yayılmasına neden olmaktadır. Enterococcus'ların antibiyotik direnci doğal ve kazanılmış direnç şeklinde sınıflandırılmaktadır. Sefalosporinler, aminoglikozitler, polimiksinler, linkomisin ve klindamisine karşı oluşan direnç doğal direnç olarak tanımlanmaktadır. Makrolitler, tetrasiklinler, kloramfenikol, trimetoprim sulfametoksazol, rifampisin, aminoglikozitler, glikopeptitler (vankomisin ve teikoplanin vb.) ve ampisiline karşı oluşan dirence ise kazanılmış direnç denilmektedir. Ampisilin, vankomisin ve gentamisin, çoklu antibiyotiğe dirençli Enterococcus 'ların tedavisinde klinik alanlarda yaygın kullanılan antibiyotiklerdir. Son yıllarda vankomisinin yaygın kullanımı sonucu vankomisine dirençli Enterococcus (VRE) suşlarının sayısında ve bununla beraber hastane kaynaklı yüksek vankomisin direncine sahip Enterococcus'ların invazyon oranında artış gözlenmiştir [6].

Enterococcus'ların patojenitesi hem antibiyotiklere olan dirençleri hem de virülans faktörleri ile ilişkilendirilmektedir. Virulans faktörleri olarak agregasyon materyalleri, jelatinaz, hücre dışı yüzey proteini bunlara örnek olarak verilebilir. Jelatinaz, jelatini, kollajeni, hemoglobini hidrolize eden bir hücre dişı metallo-endopeptidaz enzimidir. Gıdalardaki E.faecalis suşlarında jelatinaz üretim oranı, çalışmalarda genotipte jelatinaz geninin bulunmasına karşılık fenotipte bu özelliği göstermemesi üzerine değişiklik gösterebilmektedir. Hücre dişı yüzey proteininin adhezyonda ve konakçı bağışıklık sisteminden korunmada rol oynadığı düşünülmektedir. Patojenlerin konakçı dokudaki hücre dışı matrikse tutunması enfeksiyona yol açabilmektedir. Lipaz, besinlerle alınan yağların yapı taşlarına kadar parçalanması ve vücutta kullanılabilir hale getirilmesinden sorumlu olan enzimdir. $\mathrm{Bu}$ enzim sayesinde trigliserid formunda vücuda alınarak sindirim kanalında ilerleyen yağlar, yağ asitleri ve gliserole dönüştürülerek emilime hazır hale getirilir. Gıdalarda bulunan Enterococcus türleri lipaz enzimine dayanıklıdır ve aktivite sonuçları zayıf veya negatiftir [7].

DNAz, DNA'daki fosfodiester bağlarını kesen, DNA'yı kısa oligonükleotit parçalarına ya da tamamen bileşenlerine ayıran bir enzimdir. E.faecalis ve E.faecium türleri DNA bozunmasına neden olan bu enzime sahiptirler. Hücre zarfının bir parçası olan $\mathrm{S}$ tabakasının yapısında protein ve glukoprotein vardır. Enterococcus türlerinde S-tabakası peptidoglikan tabakaya bağlıdır (dış membran yoktur). S-tabakası hücreyi iyon ve $\mathrm{pH}$ değişimleri dışında ozmotik basınç ve yabancı enzimlere karşı da korur ve bazı bakteri hücrelerinde şeklin oluşumunda ve zarfın sağlamlığında rol oynar. Enterococcus türlerinin çoğunda S tabakası oluşumu pozitif gözlenir [8].

En yaygın iki Enterococcus türü olan E.faecalis ve E.faecium, çeşitli biyotik ve abiyotik yüzeylere geri döndürülemez şekilde eklenmiş bir hücre popülasyonundan oluşan, ekzopolimerik maddelerin hidratlanmış bir matrisine yerleştirilmiş biyofilm üretebilir [9]. Biyofilm, çeşitli biyotik ve abiyotik yüzeylere geri döndürülemez şekilde bağlanmış ve ekzopolimerik maddeler, proteinler, polisakkaritler ve nükleik asitlerin hidratlı bir matrisine yerleştirilmiş bir hücre popülasyonudur [10]. Biyofilmlerin yok edilmesi çok zordur ve birçok kronik enfeksiyonun kaynağıdır [11]. Biyofilmlerdeki Enterococcus'lar, planktonik olarak büyüyen Enterococcus 'lardan daha antibiyotiklere karşı daha dirençlidir, bu nedenle biyofilm oluşumunun potansiyel etkisi önemli olabilir [9].

Araştırmamızın amacı, Enterococcus türlerinin tüketime sunulan çeşitli gıda örneklerinden izolasyonu, identifikasyonu, antibiyotik dirençliliğin, biyofilm üretimlerinin ve fenotipik virülans özelliklerinin araştırılmasıdır. 


\section{Materyal ve Metot}

\subsection{Gıda Örneklerinin Toplanması}

Eylül-Aralık 2020 tarihleri içerisinde, Ankara'da bulunan çeşitli market, çiftlik, sokak satıcıları ve pazarlarında satışa sunulan 20 çiğ süt, 20 peynir, 20 çiğ tavuk (göğüs, but, kanat), 20 çiğ et (gerdan, antrikot, döş, sırt) olmak üzere toplam 80 gida örneği materyal olarak kullanılmıştır. Örnekler soğuk zincir koşullarında, steril kapların içinde laboratuvar ortamına getirilmiş ve aynı gün içinde çalışma yapılmıştır.

\subsection{Gida Örneklerinde Enterococcus} İzolasyonu ve Ön Tanımlamasının Yapılması

Araştırmamızda Enterococcus spp. izolasyonu için, Türk Gıda Kodeksi Mikrobiyolojik Kriterler Yönetmeliği'nde belirtilen esaslara göre yapılmıştır [12]. Kültürel yöntemlere göre izolatların ön tanımlaması metotta 2 aşamada yapılmıştır:

\subsection{1. Ön zenginleştirme}

Alınan örnekler 9:1 oranında Tamponlanmış Peptonlu Su'ya (Peptone Water) konulmuştur. 24 saat $37^{\circ} \mathrm{C}$ 'de inkübe edilmiştir [12].

\subsubsection{Zenginleştirme}

$10^{-1}$ dilüsyondan Slanetz-Bartley Agar'da (SBA, Merck, 105262) ekim yapılarak $48-72$ saat $37^{\circ} \mathrm{C}^{\prime}$ de inkübe edilmiştir. SBA besiyerinde üreyen tipik kırmızı ve pembe renkteki koloniler kanlı agara pasajlanarak $24-48$ saat $37^{\circ} \mathrm{C}^{\prime} \mathrm{de}$ inkübasyona bırakılmıştır [12].

\subsection{Bakteri İzolatlarının Tür Tanımlamaları}

Ön tanımlanması yapılan izolatların tür tanımlamaları Crystal Gram Positive Kit (BD BBL) ile yapılmış ve 60 bakteri örneğinin tamamının türü Enterococcus spp. olarak belirlenmiştir. İzolatların tür tayini Sağlık Bakanlığı'nın Mikrobiyoloji Referans Laboratuvarı ve Biyolojik Ürünler Daire Başkanlığı' 'na ait Ulusal Mikrobiyoloji Laboratuvar'ında MALDI TOF MS kütle spektrometresi ile yapılmıştır. Pozitif Kontrol olarak E.faecalis ATCC 29212 suşu kullanılmıştır.

\section{4. İzolatların Antibiyotik Dirençlilik} Profillerinin Belirlenmesi

Enterococcus spp. izolatlarının antibiyotik dirençliliği ve duyarlılığı Clinical and Laboratory Standards Institute (CLSI 2013) kurallarına belirlenen antibiyotiklere (gentamisin (10 $\mathrm{mcg})$, tetrasiklin (30 mcg), eritromisin (15 mcg), kloramfenikol (30 $\mathrm{mcg})$, streptomisin $(30 \mathrm{mcg})$, ampisilin (10 $\mathrm{mcg})$, vankomisin (30 mcg), siprofloksasin (10 mcg), norfloksasin (10 $\mathrm{mcg}$ ) ve teikoplanin $(30 \mathrm{mcg})$ ) Kirby-Bauer disk difüzyon yöntemiyle yapılmıştır. Mueller Hinton Agar'da, inkübasyon süresi bitiminde disklerin etrafinda oluşan inhibisyon zonlarının çapları ölçülmüştür [13].

\section{5. İzolatların Fenotipik Virülans Profilinin Belirlenmesi}

Hemolitik aktivite Koyun Kanl Agar'da $37^{\circ} \mathrm{C}$ 'de ve 24 saatte üreyen bakteri kolonilerinin hemolitik aktivitesi çevresinde eritrositlerin parçalanarak bir zon oluşturmasına göre değerlendirilmiştir [14].

Lipaz aktivitesi Tributyrin Agar'da $25-30^{\circ} \mathrm{C}^{\prime}$ da $2-3$ gün inkübe edilmiştir. Besiyeri bileşimindeki tribütirinin bulanıklığa neden olup olmadığı incelenmiştir [15].

Jelatinaz üretimi, jelatin ortamı (Nutrient Gelatine) üzerinde cam tüpler içerisinde $5 \mathrm{~mL}$ besiyeri kullanılarak yapılmıştır. Öze ile sıvı besiyerinden alınan bakteri örneği jelatin besiyerine daldırma yöntemi ile ekilmiştir. $37^{\circ} \mathrm{C}^{\prime} \mathrm{de}$ 10-30 gün inkübe edilmiştir [16].
DNaz aktivitesi, DNaz Agar üzerinde belirlenmiştir. DNaz besiyerine ekimi yapılan bakterilerin üzerin $\% 8.3$ 'lük $\mathrm{HCl}$ damlatılmış ve bakterilerinde etrafinda şeffaf zon oluşumu gözlemlenmiştir [17].

Yüzey tabakasının (S-tabakası) varlığ,$\quad 0.1 \quad \mathrm{mg} / \mathrm{mL}$ Coomassie Brilliant Blue R 250 ile güçlendirilmiş TSA besiyeri üzerindeki kültürlerin çizilmesi ile değerlendirilmiştir. TSA besiyerine eklenen $0.1 \mathrm{mg} / \mathrm{mL}$ Coomassie Brilliant Blue üzerinde besiyerindeki proteinlerin parçalanması sonucunda kolonilerin koyu mavi renkte ürediği gözlemlenmiştir [18].

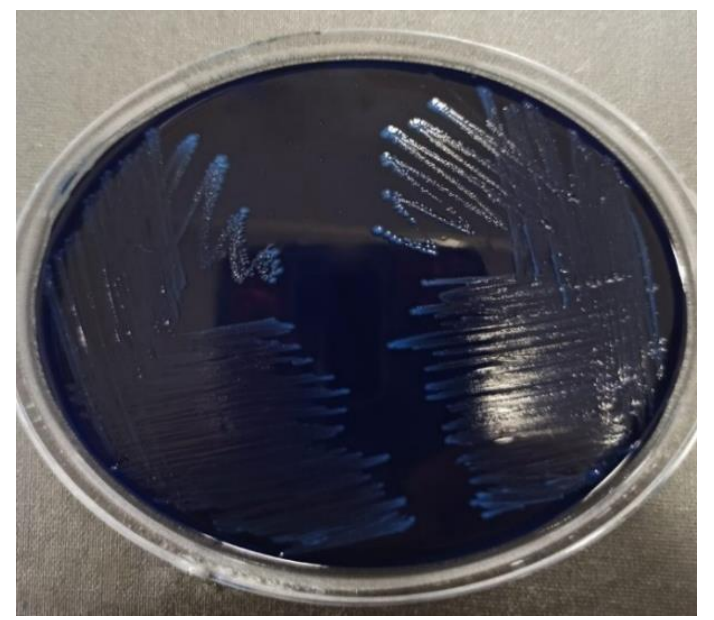

Resim 1.TSA-C besiyerinde Enterococcus 'ların görünüşü

\subsection{Biyofilm Oluşumu}

\subsubsection{Kongo Red Agar Yöntemi}

Biyofilm oluşumuna Kongo Red Agar yöntemi ve Mikroplak Yöntemi ile bakılmıştır. Suşlar kongo kırmızılı agara ekim yapıldıktan sonra $25^{\circ} \mathrm{C}$ 'de 24 saat inkübasyon sonucunda, kuru kristalize siyah koloniler oluşturan suşlar biyofilm pozitif, kırmızı veya pembe renkli koloni oluşturan suşlar ise biyofilm negatif olarak değerlendirilmiştir. Koyuluk derecesine göre sonuçlar,,++++++ şeklinde değerlendirilmiştir.

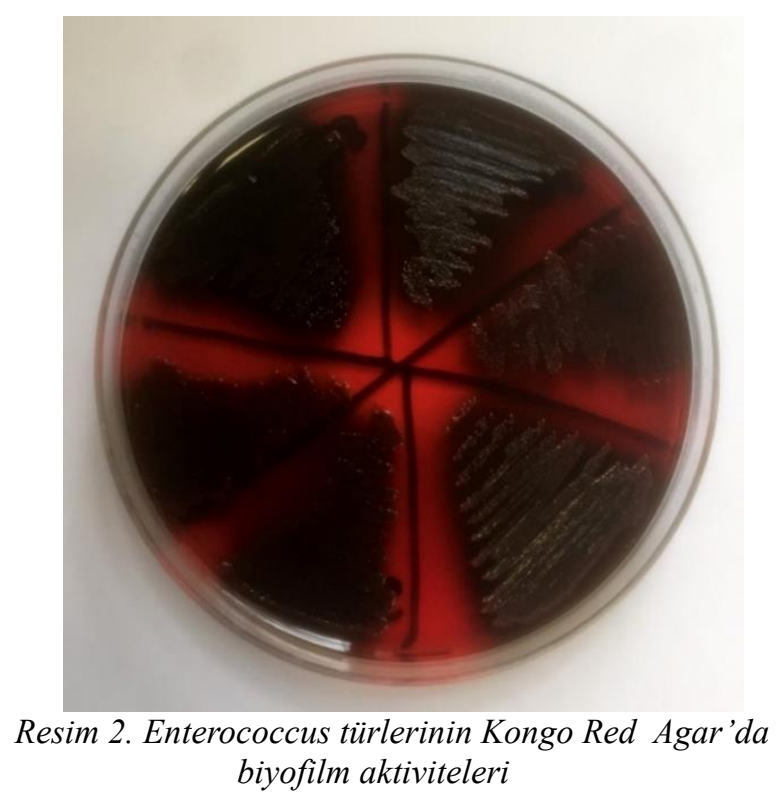

\subsubsection{Mikroplak Yöntemi}

Saflaştırılmış Enterococcus tür kolonileri, $10 \mathrm{~mL}$ Tripton Soy Broth'da süspanse edilmiş $37^{\circ} \mathrm{C}^{\prime}$ de 18 saat süreyle inkübe edilmiş ve 2 dakika boyunca $12.000 \mathrm{rpm}$ 'de santrifüjlenmiştir. Hücre topakları fosfat tamponlu çözelti (PBS) içinde, yapışma özellikleri, negatif kontrol olarak steril TSB içeren steril 96 
kuyucuklu polistiren mikrotitre plakalarının oyukları yoluyla tespit edilerek yıkanmış E. faecalis 29212 pozitif kontrol olarak kullanılmıştır. Mikrotitre plakaları 24 saat $37^{\circ} \mathrm{C}$ de inkübe edilmiş, steril PBS ile yıkanarak $28 \pm 2^{\circ} \mathrm{C}^{\prime} \mathrm{de}$ kurumaya bırakılmıştır. Kristal viyole ile boyanıp 30 dakika beklenmiştir. Kuyucuklar tekrar sterilize edilmiş deiyonize su ile yıkanmış ve oda sıcaklığında kurumaya bırakılmıştır. Yapışık hücrelere bağlanan kristal viyole boya $150 \mathrm{~mL} \% 99$ etanol içinde yeniden süspansiyon haline getirilmiş, ilgili kuyucuklardaki OD okumaları 570 ve 595 nm'de bir mikroplaka okuyucu ile değerlendirilmiştir. Aşağıdaki tablolarda belirtilen değer aralıklarına göre “+,++,+++” şeklinde değerlendirilmiştir [19].

Tablo 1. Mikrotiter plaka yönteminde biyofilm oluşturma yeteneğinin sinıflandırılması

\begin{tabular}{lc}
\hline $\begin{array}{l}\text { Cut-off değeri } \\
\text { hesaplama }\end{array}$ & $\begin{array}{c}\text { OD değerleri } \\
\text { sonuçlarının ortalaması }\end{array}$ \\
\hline $\mathrm{OD}>4 \times \mathrm{ODc}$ & $\ldots \quad \mathrm{OD}>0.236($ Güçlü) \\
\hline $2 \times$ ODc $<$ OD $\leq 4 \times$ ODc & $0.118<\mathrm{OD} \leq 0.236(1 \mathrm{liman})$ \\
\hline $\mathrm{ODc}<\mathrm{OD} \leq 2 \times \mathrm{ODc}$ & $0.059<\mathrm{OD} \leq 0.118$ (Zayıf) \\
\hline $\mathrm{OD} \leq 0.059$ & $\ldots \quad \mathrm{OD} \leq 0.059$ (Hiçbiri) \\
\hline
\end{tabular}

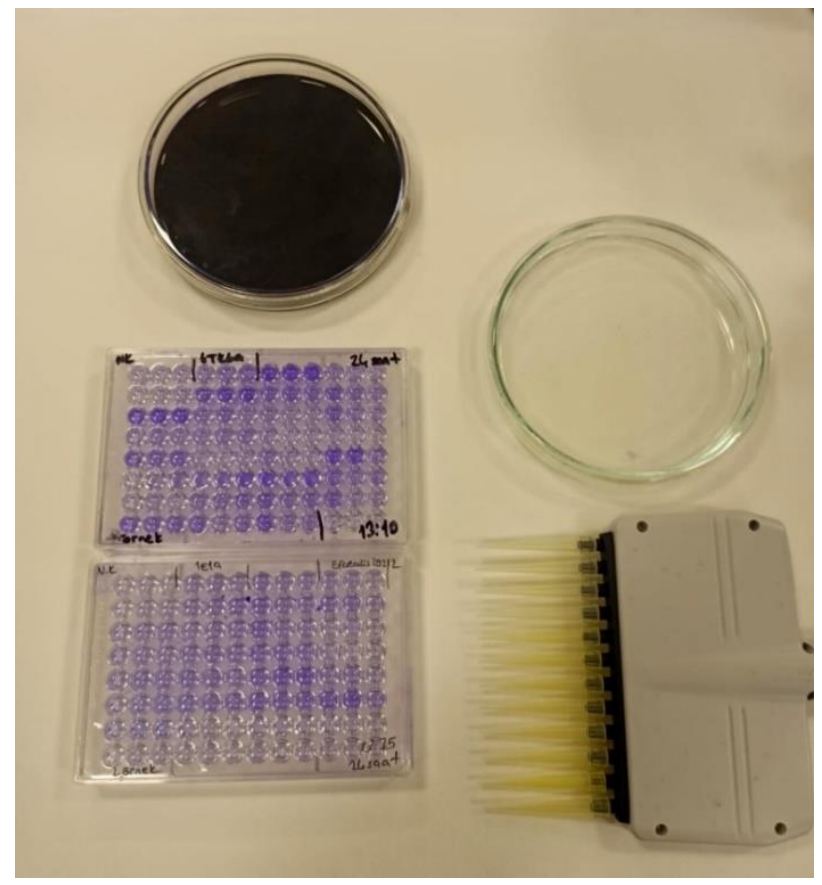

Resim E.4. Enterococcus türlerinin mikroplak yöntemiyle biyofilm aktiviteleri

\section{Araştırma Sonuçları ve Tartışma}

Tablo.2. Glda örneklerinden izole edilen Enterococcus türlerinin izole edildikleri materyallere göre dağllımları

\begin{tabular}{|c|c|c|c|c|c|}
\hline \multirow{2}{*}{$\begin{array}{l}\text { Gıda } \\
\text { örnek adı }\end{array}$} & \multicolumn{2}{|c|}{ E.faecalis } & \multicolumn{2}{|c|}{ E. faecium } & \multirow{2}{*}{$\begin{array}{c}\text { Toplam } \\
\text { İzolat } \\
\text { Sayısı }\end{array}$} \\
\hline & $\begin{array}{l}\text { Izolat } \\
\text { sayısı }\end{array}$ & $\%$ & $\begin{array}{l}\text { Izolat } \\
\text { sayısı }\end{array}$ & $\%$ & \\
\hline $\begin{array}{l}\text { Çiğ Süit } \\
(\mathbf{n = 2 0})\end{array}$ & 11 & 55 & 6 & 30 & 17 \\
\hline $\begin{array}{l}\text { Peynir } \\
(n=20)\end{array}$ & 12 & 60 & 8 & 40 & 20 \\
\hline $\begin{array}{l}\text { Çiğ Tavuk } \\
(\mathbf{n = 2 0})\end{array}$ & 10 & 50 & 1 & 5 & 11 \\
\hline $\begin{array}{l}\text { Et } \\
(n=20)\end{array}$ & 9 & 45 & 3 & 15 & 12 \\
\hline TOPLAM & 42 & 210 & 18 & 90 & 60 \\
\hline
\end{tabular}

Tablo 2'ye göre; çalışılan gıdalardan 60 Enterococcus izolatı elde edilmiş olup 42 tanesi E.faecalis ve 12 tanesi E.faecium olarak tespit edilmiştir.

Tablo.3. Gida örneklerinden izole edilen E.faecalis ve E.faecium izolatlarının disk difüzyon yöntemiyle belirlenen antibiyotik dirençlilik oranlarının antibiyotiklere göre sayısı ve oranları

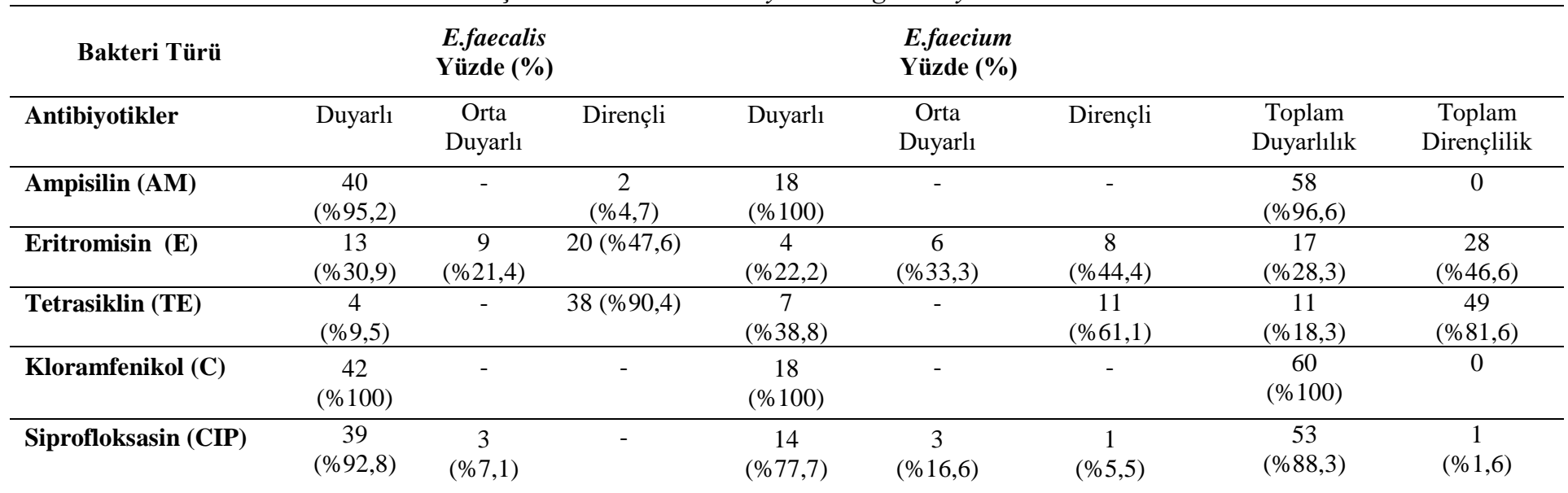




\begin{tabular}{|c|c|c|c|c|c|c|c|c|}
\hline Streptomisin (S) & $\begin{array}{c}42 \\
(\% 100) \\
\end{array}$ & - & - & $\begin{array}{c}18 \\
(\% 100)\end{array}$ & - & - & $\begin{array}{c}60 \\
(\% 100)\end{array}$ & 0 \\
\hline Gentamisin $(\mathrm{CN})$ & $\begin{array}{c}41 \\
(\% 97,6) \\
\end{array}$ & $\begin{array}{c}1 \\
(\% 2,3)\end{array}$ & - & $\begin{array}{c}18 \\
(\% 100) \\
\end{array}$ & - & - & $\begin{array}{c}59 \\
(\% 98,3) \\
\end{array}$ & 0 \\
\hline Vankomisin (VA) & $\begin{array}{c}42 \\
(\% 100)\end{array}$ & - & - & $\begin{array}{c}18 \\
(\% 100)\end{array}$ & - & - & $\begin{array}{c}60 \\
(\% 100)\end{array}$ & 0 \\
\hline Norfloksasin (NOR) & $\begin{array}{c}41 \\
(\% 97,6) \\
\end{array}$ & $\begin{array}{c}1 \\
(\% 2,3) \\
\end{array}$ & - & $13(\% 72,2)$ & $\begin{array}{c}3 \\
(\% 16,6) \\
\end{array}$ & $\begin{array}{c}2 \\
(\% 11,1) \\
\end{array}$ & $\begin{array}{c}54 \\
(\% 90) \\
\end{array}$ & $\begin{array}{c}2 \\
(\% 3,3) \\
\end{array}$ \\
\hline Teikoplanin (TEC) & $\begin{array}{c}42 \\
(\% 100)\end{array}$ & - & - & $\begin{array}{c}18 \\
(\% 100)\end{array}$ & - & - & $\begin{array}{c}60 \\
(\% 100)\end{array}$ & 0 \\
\hline
\end{tabular}

negatiftir. 60 Enterococcus izolat örneğinin tümünde $\mathrm{DNaz}$ aktivitesi pozitif bulunmuştur.

Tablo.5. Gida örneklerinden izole edilen Enterococcus spp. izolatlarının Yüzey Tabakası (S-Tabakası) Varlığına göre TSA-C renk koyulukları sonuçlarının sayısı ve yüzde oranları

\begin{tabular}{l|c|c|c}
\hline \multirow{2}{*}{ Enterococcus spp. } & \multicolumn{3}{|c}{ TSA-C Renkleri } \\
\cline { 2 - 4 } & Açı & Orta & Koyu \\
\cline { 2 - 4 } & \multicolumn{3}{|c}{ S-tabakası } \\
\cline { 2 - 4 } & Negatif & \multicolumn{2}{|c}{ Pozitif } \\
\hline \multirow{2}{*}{ E.faecalis } & $\begin{array}{c}2 \\
\% 14,2)\end{array}$ & $20(\% 90,9)$ & $20(\% 83,3)$ \\
\hline \multirow{2}{*}{ E.faecium } & $\begin{array}{c}12 \\
(\% 85,7)\end{array}$ & $\begin{array}{c}2 \\
(\% 9)\end{array}$ & $\begin{array}{c}4 \\
(\%, 6)\end{array}$ \\
\hline \multicolumn{1}{c}{ TOPLAM } & 14 & 22 & 24 \\
\hline
\end{tabular}

Tablo.3'e göre; g1da örneklerinden izole edilen E.faecalis ve E.faecium izolatlarının disk difüzyon yöntemiyle belirlenen antibiyotik dirençlilik oranlarında E.faecalis türlerinin \%100 duyarlı olduğu antibiyotikler sırasıyla kloramfenikol, streptomisin, vankomisin ve teikoplanin olarak incelenmiştir. E.faecium türlerinin \%100 duyarlı olduğu antibiyotikler sırasıyla ampisilin, kloramfenikol, streptomisin, gentamisin, vankomisin ve teikoplanin olarak incelenmiştir. En yüksek antibiyotik direnci tetrasiklinde saptanmış olup değerler E.faecalis'te 38 $(\% 90,4)$ ve E.faecium 'da $11(61,1)$ şeklindedir.

Tablo.4. Glda örneklerinden izole edilen Enterococcus spp. izolatlarının hemolitik aktivite sonuçlarına göre sayısı ve yüzde oranlart

\begin{tabular}{ccc}
\multirow{2}{*}{$\begin{array}{c}\text { Enterococcus } \\
\text { spp. })\end{array}$} & \multicolumn{2}{c}{ Hemolitik Aktivite } \\
\cline { 2 - 3 } & Pozitif & Negatif \\
\hline E.faecalis & 14 & 28 \\
$(\% 82,3)$ & $(\% 65,1)$ \\
\hline \multirow{2}{*}{ E.faecium } & 3 & 15 \\
$(\% 17,6)$ & $(\% 34,8)$ \\
\hline
\end{tabular}

TOPLAM

17

43

Tablo 4'e göre hemolitik aktivite E.faecalis'te \%82.3, E.faecium'da \%17,6 olarak saptanmıştır.

60 Enterococcus izolatının tümünde lipolitik aktivite sonucunda bulanıklık ve zonlar gözlemlenmemiş ve lipaz aktiviteleri negatif sonuç vermiştir. 60 Enterococcus izolatının tümünde bir sıvılaşma, gözlenmemiş olup bakteriler jelatinaz
Tablo.6. Glda örneklerinden izole edilen toplam 60

Enterococcus spp. türü bakterinin Kongo Red Agar ve Mikroplak Yöntemi ile elde edilen biyofilm aktivite ölçüm sonuçları

\begin{tabular}{ccccc}
\hline $\begin{array}{c}\text { Bakteri } \\
\text { Türü }\end{array}$ & \multicolumn{2}{c}{ E.faecalis } & \multicolumn{2}{c}{ E.faecium } \\
\hline \multicolumn{2}{c}{ Yöntem } & \multicolumn{2}{c}{ Yöntem } \\
\hline $\begin{array}{c}\text { Aktivite } \\
\text { Ölçüm } \\
\text { Değeri }\end{array}$ & $\begin{array}{c}\text { Kongo } \\
\text { Red } \\
\text { Agar }\end{array}$ & $\begin{array}{c}\text { Mikroplak } \\
\text { Yöntemi }\end{array}$ & $\begin{array}{c}\text { Kongo } \\
\text { Red } \\
\text { Agar }\end{array}$ & $\begin{array}{c}\text { Mikroplak } \\
\text { Yöntemi }\end{array}$ \\
\hline+ & 31 & $32(\% 53,3)$ & $6(\% 10)$ & $17(\% 28,3)$ \\
& $\% 51,6)$ & & & 10 \\
\hline++ & 11 & $8(\% 13,3)$ & $\begin{array}{c}10 \\
(\% 16,6)\end{array}$ \\
\hline+++ & 0 & $2(\% 3,3)$ & 2 & 0 \\
& & & $\% 3,3)$ & \\
\hline
\end{tabular}

Tablo 6'ya göre çeşitli gıda örneklerinden izole edilen 60 adet Enterococcus spp. türü bakterinin kongo red agar'da biyofilm aktivitesinin 37'sinde $(\% 61,6)$ zayif, 21 'inde $(\% 35)$ orta kuvvetli, 2‘sinde (\%3.3) kuvvetli biyofilm görülmüştür. 
Kuvvetli biyofilm oluşturan bakteri türlerinden ikisi de E.faecium'dur.

Mikroplak yönteminde $37^{\circ} \mathrm{C}^{\prime} \mathrm{de} \quad 48$ saat inkübasyona bırakılan 60 izolat arasında en yüksek biyofilm değerine sahip olanı E.faecalis türü süt örneğidir ve biyofilm değeri $595 \mathrm{~nm}$ 'de 2,211'dir. Biyofilm değeri en düşük olan izolat ise E.faecium türüne ait olup yine süt örneğinden elde edilmiştir ve biyofilm değeri 595 nm'de 0,022'dir. 48 saatlik inkübasyon süresinde de biyofilm değeri yüksek olan izolatların çoğunlukla E.faecalis türüne ait olduğu görülmüştür. Toplam biyofilm aktivitesi E.faecalis'te 42 (\%70), E.faecium'da $18 \quad(\% 30)$ olarak saptanmıştır.

Enterococcus'lar, hayvanların bağırsak florasındaki yaygınlığa bağlı olarak özellikle hayvansal gıdalar başta olmak üzere pek çok gıdada bulunabilmektedir. $\mathrm{Bu}$ nedenle birçok çalışmada E.faecalis ve E.faecium'un fekal kontaminasyon göstergesi olarak değerlendirildiği görülmektedir. Ancak pek çok gıdada $E$. faecalis'in yaygın bulunuşunun her zaman için doğrudan fekal kontaminasyon göstergesi olarak değerlendirilmemesi gereğine de değinilmektedir. Peynir ve et gibi belirli hayvansal ürünlerin veya örneğin zeytin gibi fermente edilmiş bitki ürünlerinin fermantasyonu ve olgunlaşmasında faydalı olabildikleri gibi bir gıda kontaminantı olarak istenmeyebilir [20], [21]. Enterococcus'ların pastörizasyondan etkilenmemeleri, geniş $\mathrm{pH}$ veya örneğin zeytin gibi fermente edilmiş bitki ürünlerinin fermantasyonu ve olgunlaşmasında faydalı olabildikleri gibi bir gıda kontaminantı olarak istenmeyebilir [20], [21]. Enterococcus'ların pastörizasyondan etkilenmemeleri, geniş $\mathrm{pH}$ aralıklarında ve yüksek $\mathrm{NaCl}$ konsantrasyonunda büyüyebilmeleri yemeye hazır gıdaların kalıntı mikrobiyotasını oluşturabilirler [22], [23].

Çalışmamızda 80 farklı gıda örneğinden (çiğ süt, peynir, çiğ tavuk, et) yapılan izolasyon ve tür tanımlamaları sonucunda 60 bakteri izolatının 42'si (\%70) E.faecalis ve 18'i (\%30) E.faecium olarak belirlenmiştir. Ülkemizde ve yurt dişında yapılan son çalışmalarda gıda kaynaklı Enterococcus 'ların beyaz peynirden, tulum peynirinden, geleneksel Türk sucuğundan, tavuk, sığır eti, Cheddar peyniri, beyaz peynir, krem peynir, yoğurt, sütlü tatlılar gibi gıdalardan karabiber ve kırmızı biber gibi baharatlardan yaygın olarak izole edildiği gözlenmektedir [3], [4], [5]. Oruç ve ark. İran ve Türk beyaz peynirlerinden yaptıkları bir çalışmada 12 E.faecalis ve 8 E.faecium suşu elde etmişlerdir [24].

$\mathrm{Bu}$ çalışmalarda bizim sonuçlarımızla paralel olarak Enterococcus türlerinin et ve süt ürünlerinde yüksek oranda bulunduğu tespit edilmiştir. Gomes ve ark. Brezilya gıda ürünleri ile (çiğ ve pastörize süt, et ürünleri, peynirler ve sebzeler) yaptıkları çalışmada gıda örneklerinin \%52,5'ini Enterococcus olarak tespit etmişlerdir. Pavia ve ark. Enterococcus izolatlarını Catanzaro (İtalya) perakende satış noktalarında satılan etlerden (sığır, tavuk, hindi, kuzu ve domuz eti) çoğunluğu tavuk eti $(\% 65,4)$ olmak üzere $\% 45$ 'inden, izole etmişlerdir. Bulunan türlerde en sık rastlananları çiğ süt ve ette E. faecium ve E. faecalis iken sebzelerde E. casseliflavus olarak bulunmuştur [25], [26], [27].

Suzzi ve ark. 2000 yılında İtalyan keçi peyniri ile yaptıkları bir çalışmada en yaygın olan Enterococcus türlerinin E.faecalis ve E.faecium olduğunu tespit etmişlerdir. Suzzi ve ark. E. faecium ve E. faecalis'in çevresel örneklerden en sık izole edilen türler olduğunu ve bu çalışmada olduğu gibi, istenmeyen enterokokların varlığının bozulma sorunlarına neden olabileceğini ve peynir üretimi sırasında kötü hijyen koşullarından kaynaklanabileceğini doğrulamıştır. Suzzi ve arkadaşlarının sonuçları, araştırmamızda da gıdalarda E.faecalis (\%70) ve E.faecium (\%30) yüksek sıklıkta izole edilen türler olması nedeni ile uygunluk göstermiştir [28].

Wessels ve ark. (1988) E. faecalis'in (izolatların \%73.4'ü) süzme peynirde yaygın olan tür olduğunu, Rao ve ark. (1986), Hindistan'da yaptıkları çalışmada, E.faecalis'in çiğ sütte, Efaecium 'un kuru süt hariç tüm süt ürünlerinde baskın olduğunu bildirmişlerdir [29]. Litopoulou-Tzanetaki (1990) çalışmasında, Kefalotyri peynirindeki aroma gelişimi için önemli olan diğer laktik asit bakterileri ile birlikte kullanılan E.durans ve E.faecium 'u tespit etmiştir [30].

Ülkemizde yapılan çalışmalarda Çıtak ve ark. Enterococcus spp. varlığı açısından analiz ettikleri 30 Türk beyaz peynir numunesinden elde ettikleri 101 izolatından 62 E. faecalis, 25 E.faecium, 7 E.durans, 5 E.mundtii ve 2 E.Hirae elde etmişlerdir [31]. Çıtak ve ark. Yaptıkları bir başka çalışmada 78 çiğ süt örneğinden izole ettikleri 177 Enterococcus izolatının \%54.2'sini Enterococcus faecalis ve \%29'unu E.faecium olarak tanımlamışlardır [32].

Enterococcus'ların antibiyotik direnci doğal (intrinsik) direnç ve kazanılmış direnç şeklinde sınıflandırılmaktadır. Enterococcus antibiyotik direnci üzerine yapılan çalışmalar değerlendirilirken ortaya çıkan görüntü, çoklu ilaca dirençli suşların olası oluşumudur. Enterococcusal antibiyotik direnci klinik alana özel değildir, aynı zamanda gıda endüstrisinde de yaygındır. Daha önce hastanede ya da antibiyotik kullanmadıkları zaman hastaneye yatırılan bireylerde VRE varlığı, VRE'nin gıda zinciri yoluyla olabileceğini de düşündürmektedir.

Pavia ve ark. (2000), İtalya'da kontamine beyaz peynir, tavuk, kuzu, hindi ve sığır etinden izole ettikleri Enterococcus'ların Vankomisine dirençli Enterococcus (VRE) ve Teikoplanine dirençli Enterococcus (TRE) düzeylerini sırasıyla $\% 29$ ve $\% 39$ olarak tespit etmişlerdir. Tavuk örneklerinde vankomisin direncini daha yüksek $(\% 76,5)$ bulmuşlardır. Teikoplanine (TRE) karşı genel direnç \%30 iken, pozitif olanlar arasında TRE izolatların \%66.7'sini temsil ediyordu. En s1k görülen izolatlar E.faecium (\%35.6) ve E.faecalis (\%33.3) idi. Vankomisin ve teikoplanine direnci $E$. faecium'un sirasiyla $\% 75$ ve $\% 78,5$ 'inde ve E. faecalis'in $\% 40$ ve \%46.7'sinde gözlemlemişlerdir. Çoğu suşun ampisiline (\%80) duyarl1, metisiline (\%88.9) dirençli olduğunu görmüşlerdir. İzolatlarda en yüksek direnç prevalansını streptomisin (\%88.9), tetrasiklin $(\% 84.4)$ ve eritromisin $(\% 75.6)$ olarak bulmuşlardır. Vankomisine direncin, metisilin, teikoplanin, eritromisin, tetrasiklin ve kloramfenikol ile önemli ölçüde ilişkili olduğunu saptamışlardır [25].

$\% 80$ 'den fazla insan enfeksiyonları ile ilişkili Enterococcus'ların en önemlileri E. faecalis'tir [33]. Son yıllarda, VRE ile kolonizasyonun sıklıkla sağlık ortamı dışındaki hayvan, gida ve çevresel rezervuarlardan kaynaklandığı öne sürülmüştür. $\mathrm{Bu}$ da $E$. faecalis'in patojenik potansiyelinin $E$. faecium'dan daha fazla olduğunu düşündürmektedir [34], [25].

Ülkemizde yapılan çalışmalarda Çıtak ve ark. 30 Türk beyaz peynirinden elde ettikleri Enterococcus spp.'nin 101 izolatından 62 E. faecalis ve 25 E.faecium türünün streptomisin, eritromisin, oksasilin ve vankomisine karşı direncini araştırmış ve E. faecalis izolatlarının \%96.8'inde, E. faecium izolatlarının \%76'sında vankomisine direnç saptamışlardır ve bu çalışma ile Türk beyaz peynirinde Enterococcus'ların, vankomisine dirençli suşların varlığını doğrulamışlardır [31].

Çıtak ve ark. bir başka çalışmalarında antibiyotiklerin çiğ sütten elde edilen Enterococcus izolatlarına karşı in vitro 
aktivitelerini belirlemek için disk-difüzyon yöntemini uygulamış ve Enterococcus izolatlarında yüksek oranda oksasilin, streptomisin ve eritromisin direnci olduğunu görmüşlerdir $(\% 95$, 97 ve \%86). E.faecalis izolatlarının sirasıyla $\% 48$ ve $\% 52$ 'sinde vankomisin ve teikoplanin direnci, E. faecium için $\% 26$ ve $\% 33$ vankomisin ve teikoplanin direnci gözlemlemişlerdir [35].

Bizim sonuçlarımıza göre de E.faecalis türlerinin E.faecium'a göre antibiyotiklere daha duyarlı oldukları görülmüştür. E.faecalis türlerinin duyarlı olduğu antibiyotikler sirasiyla kloramfenikol 42 (\%100), streptomisin 42 (\%100), vankomisin $42(\% 100)$ teikoplanin $42(\% 100)$, gentamisin 41 $(\% 97,6)$, norfloksasin $41(97,6)$, ampisilin $40(\% 95,2)$ olarak incelenmiştir. E.faecium türlerinin duyarlı olduğu antibiyotikler sirasiyla ampisilin (\%100), kloramfenikol 18 (\%100), streptomisin 18 (\%100), gentamisin 18 (\%100), vankomisin 18 (\%100) ve teikoplanin 18 (\%100), siprofloksasin $14(\% 77,7)$, norfloksasin $13(\% 72,2)$ olarak incelenmiştir. En yüksek antibiyotik direnci tetrasiklinde saptanmış olup değerler E.faecalis'te $38(\% 90,4)$ ve E.faecium'da $11 \quad(\% 61,1)$ şeklindedir. E.faecalis ve E.faecium için toplam antibiyotik duyarlılık oranları ampisilinde $58(\% 96,6)$, eritromisinde 17 (\%28,3), tetrasiklinde $11(\% 18,3)$, kloramfenikolde 60 (\%100), siprofloksasinde 53 (\%88,3), streptomisinde 60 (\%100), gentamisinde 59 (\%98,3), vankomisinde 60 (\%100), norfloksasinde 54 (\%90), teikoplaninde 60 (\%100) olarak incelenmiştir. E.faecalis ve E.faecium için toplam antibiyotik dirençlilik oranları tetrasiklinde $49(\% 81,6)$, eritromisinde 28 $(\% 46,6)$, siprofloksasinde $1(\% 1,6)$, norfloksasinde $2(\% 3,3)$ olarak bulunmuş ve kloramfenikol, streptomisin, gentamisin, vankomisin, teikoplanin ve ampisilinde toplam dirençlilik 0'dır.

Araştırmamızda süt ve süt ürünleri, et ve et ürünleri gibi gida örneklerinden izole edilen toplam 60 Enterococcus izolatının en fazla vankomisin $60(\% 100)$, kloramfenikol 60 (\%100), teikoplanin 60 (\%100), streptomisine 60 (\%100) duyarl, tetrasiklin $49(\% 81,6)$ ve eritromisine $28(\% 46,6)$ dirençli olduğu tespit edilmiştir.

Ülkemizde son yıllarda yapılan Oruç ve ark. (2021) çalışmasında Türk beyaz peynirlerinden izole ettikleri E.faecalis ve E.faecium suşlarında çalıştıkları kloramfenikol (duyarlı), tetrasiklin (duyarlı), vankomisin (duyarlı), gentamisin (duyarlı), eritromisin (orta duyarlı) ve ampisilin (8 duyarlı ve 14 dirençli suş) antibiyotikleri ile elde ettikleri sonuçlar bizim sonuçlarımızı desteklemiştir [24].

Ülkemizde yapılan çalışmalarda Şanlıbaba ve ark. (2018) peynir ile yaptıkları çalışmada direnç fenotipini; kanamisin (\%98.6), ampisilin (\%48.8), siprofloksasin (\%45.5), eritromisin (\%18.8), tetrasiklin (\%11.7), kloramfenikol (\%4.2), gentamisin (\%3.8) ve streptomisin (\%1.4) şeklinde tespit etmişlerdir. Suşların hiçbirini vankomisine dirençli bulmamışlardır. E. faecium suşları antibiyotik direnç seviyeleri ile gösterildiği gibi E.faecalis suşlarından daha dirençli fenotipler göstermiş ve E.faecium ve E.faecalis suşlarının antibiyotiklere karşı dirençlerinin de istatistiksel olarak anlamlı olduğu görülmüştür $(\mathrm{p}<0.05)$. Toplamda, E.faecium'un \%100'ü ve E.faecalis suşlarının \%88,8'i birden fazla ilaca dirençli bulunmuştur [35].

Son yapılan araştırmalarda gidalardan izole edilen Enterococcus'ların antibiyotik direnç özelliklerinin yanında potansiyel virülans faktörleri yönüyle de incelenmesinin gerektiği vurgulanmaktadır [1], [36], [37], [38], [39]. Araştırmamızda virulans karakterleri olarak Enterococcus türlerinin hemolitik aktivitesini E.faecalis'te $14 \% 82.3$, E.faecium'da $3 \% 17,6$ olarak saptadık. Lipaz ve jelatinaz aktivitesi negatif bulduk. DNAz aktivitesini bütün E.faecalis
(\%100) ve E.faecium (\%100) türlerinde pozitif gözlemledik. Slayer tabakası bulundurma oranlarını E.faecalis'te 20'si $(\% 83,3)$, E.faecium'da $4(\% 16,6)$ olarak gözlemledik.

Ülkemizde ise İspirli ve ark. (2017) Türk beyaz peyniri ile yaptıkları çalışmada Enterococcus suşları için tam hemolitik aktivite gözlemlememişler ve kısmi hemolitik aktivite olarak 12 suştan 8'inde gözlemlemişlerdir [40].

Semedo ve ark. koyun peyniri ve sütten izole ettikleri 20 farklı türdeki 164 Enterococcus suşundan koyun kanlı agarda yaptıkları hemolitik aktivite sonucuna göre bütün suşlarda hemolitik aktivite gözlemlemişler ve bu özelliğin Enterococcus'larda yaygın olduğunu tespit etmişlerdir [14].

Lauková ve ark. Slovakya'da 283 keçiden çiğ keçi sütü (53) örnekleri toplamış ve elde ettikleri Enterococcus izolatlarında jelatinaz genine rastlamamışlardır [41].

Igbinosa ve ark. (2020) çalışmalarında gıdalardan izole ettikleri 59 Enterococcus izolatının fenotipik virulans özelliklerinden: S-layer 59 (\%100); jelatinaz üretimi 19 (\%32,2); ve $\beta$-hemoliz, 21 (\%35.6) şeklinde bulmuşlardır [8].

Semedo ve ark. çalışmalarında çoğunluğu gıda kaynaklı suşların (\%63) \%49'unda lipaz aktivitesi saptamıştır. Pozitif fenotipleri E.faecalis (\%51), E.durans (16\%) ve E.faecium (\%11) olarak bulmuşlardır. \%70'i gıda kaynaklı ve sadece $\% 22$ 'si klinik olan suşların \%22'sinde deoksiribonükleaz (DNaz) üretimi tespit edilmiştir [14].

Semedo ve ark. (2003) ve İgbinosa ve ark. (2019) sonuçları ile çalışmamızda 60 Enterococcus izolatına uyguladığımız jelatinaz aktivitesinin negatif sonuç göstermesi jelatinaz aktivitesinin virulans karakteri olarak gidalarda Enterococcuslar' da önemini ortaya çıkarmıştır [14], [8].

Biyofilmler çeşitli biyotik ve abiyotik yüzeylere geri döndürülemez şekilde bağlanmış ve ekzopolimerik maddeler, proteinler, polisakkaritler ve nükleik asitlerin hidratlı bir matrisine yerleştirilmiş bir hücre popülasyonudur. Biyofilmlerin yok edilmesi çok zordur ve birçok kronik enfeksiyonun kaynağıdır. Ulusal Sağlık Enstitüleri'ne göre biyofilmler tıbbi olarak önemlidir ve vücuttaki mikrobiyal enfeksiyonların \% 80 'inden fazlasını oluşturur [42].

Biyofilmlerdeki Enterococcuslar, planktonik olarak büyüyen Enterococcus'lara göre antibiyotiklere karşı daha dirençlidir, bu nedenle biyofilm oluşumunun potansiyel etkisi önemli olabilir [42].

Çalışmamızda çeşitli gıda örneklerinden izole edilen 60 adet Enterococcus spp. türü bakterinin Kongo Red Agar yöntemiyle bakılan biyofilm aktivitesi sonuçlarına göre 2‘si (\%3.3) kuvvetli, 22 'si (\%36.6) orta kuvvetli, 36’sı (\%60) zayıf biyofilm pozitif bulunmuştur. En kuvvetli biyofilm oluşumu iki E.faecium izolatında saptanmıştır.

Mikroplak yöntemiyle bakılan biyofilm aktivite sonuçlarına göre ise $37^{\circ} \mathrm{C}$ 'de 48 saat inkübasyona birakılan 60 izolat arasında en yüksek biyofilm değerine sahip olanı süt örneğinden elde edilen E.faecalis'tir ve biyofilm değeri 595 nm'de 2,211'dir. Biyofilm değeri en düşük olan izolat ise E.faecium türüne ait olup yine süt örneğinden elde edilmiştir ve biyofilm değeri 595 nm'de 0,022 'dir. 48 saatlik inkübasyon süresinde de biyofilm değeri yüksek olan izolatların çoğunlukla E.faecalis türüne ait olduğu görülmüştür.

$\mathrm{Bu}$ çalışmalar sonucu E. faecalis bakteri türlerinin E.faecium türlerine göre daha yüksek sayıda biyofilm oluşturduklarını gözlemledik. Bu veriler $E$. faecalis'in $E$. faecium'dan daha sik biyofilm ürettiğini ve biyofilm oluşumunun Enterococcus enfeksiyonunun patogenezinde önemli bir faktör olabileceğini düşündürmektedir. 
Mohamed ve ark. yaptığı çalışmada bir biyofilmin $E$. faecalis ve E. faecium tarafından farklı biyomateryaller üzerine yapışmasını ve üretimini göstermiş ve Enterococcus'ların biyofilm üretme yeteneği olarak üreteral stentler, intravasküler kateterler, safra stentleri ve silikon gastrostomi cihazları gibi çeşitli tıbbi cihazlara bağlanma kapasitesini göstermişlerdir [9].

Di Rosa ve diğer araştırmacılar E.faecalis suşlarının tamamına yakınında $(\% 95,2)$ biyofilm oluşturma yeteneği tespit etmişlerdir. E. faecalis izolatlarının E. faecium'dan daha sık biyofilm ürettiğini öne sürmüşlerdir [43].

\section{Sonuç}

Amaçlarımız doğrultusunda elde ettiğimiz sonuçlar; gıda ürünlerinden izole edilen Enterococcus'lara çeşitli özellikler kazandıran virülans genler ve antibiyotik direnliliği hakkında bilgiler ortaya konulmuş, direncin oluşmasını engelleme veya oluşan direnci azaltmaya yönelik ileride yapılacak çalışmalara yön verecektir. $\mathrm{Bu}$ bilgiler 1şı̆̆ında, direncin gelişiminin önlenmesinin önemi, dolayısıyla gida ve hayvancılık işletmelerinde bilinçli ve kontrollü üretim yapılması gerekliliği vurgulanarak, ülke ekonomisi ve toplumun refah düzeyinin arttırılması ile yaygın bir etki sağlayacaktır

$\mathrm{Bu}$ çalışma ile normal floranın firsatçı patojenleri olarak insanlarda, nozokomiyal kan dolaşımı, üriner sistem infeksiyonlarına, bakteriyemiye, endokardite, intraabdominal, yumuşak doku infeksiyonlarina ve neonatal sepsis gibi ciddi hastalıklara yol açan Enterococcus'ların gida zinciri aracılığı ile insanlara bulaşabileceği bilincinin kazandırılması ve hayvansal gıda tüketiminin daha bilinçli yapılması gerektiği vurgulanmıştır.

Ayrıca Enterococcus'lardaki hemolitik aktivite, biyofilm oluşumu ve diğer virulans faktörleri klinik alanda izole edilen Enterococcus izolatlarının yanında gida kaynaklı izolatlarda da bulunabileceği ve bakterinin patojenitesini etkileyebileceği düşünülmektedir.

\section{Teșekkür}

Çalışmamız, Gazi Üniversitesi Bilimsel Araştırma Projeleri (BAP) Müdürlüğü'nün 05/2020-19 kodlu projesiyle desteklenmiştir. Desteklerinden dolayı Gazi Üniversitesi Bilimsel Araştırma Projeleri Birimi’ne teşekkürlerimizi sunarız.

\section{Kaynakça}

[1] Franz, C. M., Muscholl-Silberhorn, A. B., Yousif, N. M., Vancanneyt, M., Swings, J., \& Holzapfel, W. H. (2001). Incidence of virulence factors and antibiotic resistance among enterococci isolated from food. Applied and environmental Microbiology, 67(9), 4385-4389.

[2] Oryaşın, E. (2008). Çeşitli çevresel kaynaklardan izole edilen enterokokların disk difüzyon yöntemi ile antibiyotik duyarlılıklarının tespiti (Doctoral dissertation, Adnan Menderes Üniversitesi).

[3] Klein, G. (2003). Taxonomy, ecology and antibiotic resistance of enterococci from food and the gastro-intestinal tract. International journal of food microbiology, 88(2-3), 123-131.

[4] İşleroğlu, H., Yıldırım, Z., \& Yıldırım, M. (2008). Identification and izolation of lactic acid bacterium having antimicrobial activity from traditionaly produced cheese. Journal of the Agricultural Faculty of Gaziosmanpaşa University.
[5] Khan, H., Flint, S., \& Yu, P. L. (2010). Enterocins in food preservation. International journal of food microbiology, 141(1-2), 1-10.

[6] Toğay, S. Ö., \& Temiz, A. (2011). Gıda kaynaklı enterokokların gida ve insan sağlığı yönünden önemi. Glda, 36(5), 303-310.

[7] Yu, M. K., Kim, M. A., Rosa, V., Hwang, Y. C., Del Fabbro, M., Sohn, W. J., \& Min, K. S. (2019). Role of extracellular DNA in Enterococcus faecalis biofilm formation and its susceptibility to sodium hypochlorite. Journal of Applied Oral Science, 27.

[8] Igbinosa, I. H., Beshiru, A., Egharevba, N. E., \& Igbinosa, E. O. (2020). Distribution of Enterobacteria in Ready-to-Eat Food in Cafeterias and Retail Food Outlets in Benin City: Public Health Implications. Journal of Community Medicine and Primary Health Care, 32(2), 80-94.

[9] Mohamed, J. A., \& Huang, D. B. (2007). Biofilm formation by enterococci. Journal of medical microbiology, 56(12), 1581-1588.

[10]Bollinger, N., Hassett, D. J., Iglewski, B. H., Costerton, J. W., \& McDermott, T. R. (2001). Gene expression in Pseudomonas aeruginosa: evidence of iron override effects on quorum sensing and biofilm-specific gene regulation. Journal of bacteriology, 183(6), 1990-1996.

[11]Lewis, K. (2001). Riddle of biofilm resistance. Antimicrobial agents and chemotherapy, 45(4), 999-1007.

[12]Kodeksi, T. G. (2011). Türk Gıda Kodeksi Mikrobiyolojik Kriterler Yönetmeliği. $R G, 29(2011), 28157$.

[13]Wayne, P. A. (2011). Clinical and laboratory standards institute. Performance standards for antimicrobial susceptibility testing.

[14]Semedo, T., Almeida Santos, M., Martins, P., Silva Lopes, M. F., Figueiredo Marques, J. J., Tenreiro, R., \& Barreto Crespo, M. T. (2003). Comparative study using type strains and clinical and food isolates to examine hemolytic activity and occurrence of the cyl operon in enterococci. Journal of Clinical Microbiology, 41(6), 2569-2576.

[15]Jeong, J. Y., Jo, Y. H., Kim, S. B., Liu, Q., Lee, J. W., Mo, E. J., .. \& Lee, M. K. (2015). Pancreatic lipase inhibitory constituents from Morus alba leaves and optimization for extraction conditions. Bioorganic \& medicinal chemistry letters, 25(11), 2269-2274.

[16]Kanemitsu, K., Nishino, T., Kunishima, H., Okamura, N., Takemura, H., Yamamoto, H., \& Kaku, M. (2001). Quantitative determination of gelatinase activity among enterococci. Journal of microbiological methods, 47(1), 1116.

[17]Omar, N. B., Castro, A., Lucas, R., Abriouel, H., Yousif, N. M., Franz, C. M., ... \& Gálvez, A. (2004). Functional and safety aspects of enterococci isolated from different Spanish foods. Systematic and Applied Microbiology, 27(1), 118130.

[18]Bernoth, E. M. (1990). Autoagglutination, growth on tryptone-soy-Coomassieagar, outer membrane protein patterns and virulence of Aeromonas salmonicida strains. Journal of Fish Diseases, 13(2), 145-155.

[19]Stepanović, S., Vuković, D., Hola, V., Bonaventura, G. D., Djukić, S., Ćirković, I., \& Ruzicka, F. (2007). Quantification of biofilm in microtiter plates: overview of testing conditions and practical recommendations for assessment of biofilm production by staphylococci. Apmis, 115(8), 891899. 
[20]Moreno, M. F., Sarantinopoulos, P., Tsakalidou, E., \& De Vuyst, L. (2006). The role and application of enterococci in food and health. International journal of food microbiology, 106(1), 1-24.

[21]Ben Braïek, O., \& Smaoui, S. (2019). Enterococci: between emerging pathogens and potential probiotics. BioMed Research International, 2019.

[22]Ghosh, A., \& Zurek, L. (2015). Antibiotic resistance in Enterococci: A food safety perspective. In Antimicrobial Resistance and Food Safety (pp. 155-180). Academic Press.

[23]Hanchi, H., Mottawea, W., Sebei, K., \& Hammami, R. (2018). The genus Enterococcus: between probiotic potential and safety concerns-an update. Frontiers in microbiology, 9, 1791.

[24]Oruc, O., Cetin, O., Darilmaz, D. O., \& Yüsekdag, Z. N. (2021). Determination of the biosafety of potential probiotic Enterococcus faecalis and Enterococcus faecium strains isolated from traditional white cheeses. $L W T, 148,111741$.

[25]Pavia, M., Nobile, C. G., Salpietro, L., \& Angelillo, I. F. (2000). Vancomycin resistance and antibiotic susceptibility of enterococci in raw meat. Journal of food protection, 63(7), 912-915.

[26]Gelsomino, R., Vancanneyt, M., Cogan, T. M., Condon, S., $\&$ Swings, J. (2002). Source of enterococci in a farmhouse raw-milk cheese. Applied and Environmental Microbiology, 68(7), 3560-3565.

[27] Saavedra, L., Taranto, M. P., Sesma, F., \& de Valdez, G. F. (2003). Homemade traditional cheeses for the isolation of probiotic Enterococcus faecium strains. International journal of food microbiology, 88(2-3), 241-245.

[28]G., Suzzi, M., Caruso, F., Gardini, A., Lombardi, L., Vannini, M. E., Guerzoni and M. T., Lanorte, "A survey of the enterococci isolated from an artisanal Italian goat's cheese (semicotto caprino)," Journal of Applied Microbiology, vol. 89 pp. 2, 267-274, 2000.

[29]Devriese, L. A., Pot, B., Van Damme, L., Kersters, K., \& Haesebrouck, F. (1995). Identification of Enterococcus species isolated from foods of animal origin. International journal of food microbiology, 26(2), 187-197.

[30]Litopoulou-Tzanetaki, E. (1990). Changes in numbers and kinds of lactic acid bacteria during ripening of Kefalotyri cheese. Journal of Food Science, 55(1), 111-113.

[31]Çitak, S., Yucel, N., \& Orhan, S. (2004). Antibiotic resistance and incidence of Enterococcus species in Turkish white cheese. International Journal of Dairy Technology, 57(1), 27-31.

[32]Citak, S., Yucel, N., \& Mendi, A. (2005). Antibiotic resistance of enterococcal isolates in raw milk. Journal of food processing and preservation, 29(3-4), 183-195.

[33]Jett, B. D., Huycke, M. M., \& Gilmore, M. S. (1994). Virulence of enterococci. Clinical microbiology reviews, 7(4), 462-478.

[34]Giraffa, G. (2002). Enterococci from foods. FEMS microbiology reviews, 26(2), 163-171.

[35]Sanlibaba, P., \& Senturk, E. (2018). Prevalence, characterization and antibiotic resistance of enterococci from traditional cheeses in Turkey. International Journal of Food Properties, 21(1), 1955-1963.

[36]Hugas, M., Garriga, M., \& Aymerich, M. T. (2003). Functionalty of enterococci in meat products. International journal of food microbiology, 88(2-3), 223-233.

[37]Hummel, A., Holzapfel, W. H., \& Franz, C. M. (2007). Characterisation and transfer of antibiotic resistance genes from enterococci isolated from food. Systematic and applied microbiology, 30(1), 1-7.

[38]Theilacker, C., Sanchez-Carballo, P., Toma, I., Fabretti, F., Sava, I., Kropec, A., ... \& Huebner, J. (2009). Glycolipids are involved in biofilm accumulation and prolonged bacteraemia in Enterococcus faecalis. Molecular microbiology, 71(4), 1055-1069.

[39]Carlos, A. R., Semedo-Lemsaddek, T., Barreto-Crespo, M. T., \& Tenreiro, R. (2010). Transcriptional analysis of virulence-related genes in enterococci from distinct origins. Journal of applied microbiology, 108(5), 15631575.

[40]İspirli, H., Demirbaş, F., \& Dertli, E. (2017). Characterization of functional properties of Enterococcus spp. isolated from Turkish white cheese. $L W T, 75,358-365$.

[41]Lauková, A., Focková, V., \& Pogány Simonová, M. (2021). Enterococcal Species Associated with Slovak Raw Goat Milk, Their Safety and Susceptibility to Lantibiotics and Durancin ED26E/7. Processes, 9(4), 681.

[42]İlhan, G. Ü. N., \& Ekinci, F. Y. (2009). Biyofilmler: yüzeylerdeki mikrobiyal yaşam. Glda, 34(3), 165-173.

[43]Di Rosa, R., Creti, R., Venditti, M., D'Amelio, R., Arciola, C. R., Montanaro, L., \& Baldassarri, L. (2006). Relationship between biofilm formation, the enterococcal surface protein (Esp) and gelatinase in clinical isolates of Enterococcus faecalis and Enterococcus faecium. FEMS microbiology letters, 256(1), 145-150. 